Tatiana Wrocławska*

\title{
PERMANENCE (STABILITY) OF AN EMPLOYMENT RELATIONSHIP OF OLDER EMPLOYEES - ANALYSIS OF CHANGES
}

\section{Introduction}

The aim of this study is to analyse the changes in Polish legislation that have taken place in the last twenty years with respect to sustainability of employment relationship in elderly employees. The fact that the very title of this study indicates elderly employees as an object of protection somewhat automatically implies that employment of this category of employees is protected, which poses the question about the extent and level of this protection. Despite the terminological diversity, which can still be encountered at times ${ }^{1}$, the category of elderly employees has been used in legal literature for a long time. It developed in response to the need to apply special legal measures to this category of employees, as it was classified in the group exposed to a very high risk of unemployment, next to young people, pregnant women, disabled people, etc. On the other hand, however, elderly employees enjoy some privileges, as their employee rights increase together with the duration of service and include, e.g. employment sustainability which intensifies with the imminent end of professional activity and is often identified in the literature with the rule of seniority ${ }^{2}$.

* Ph.D., University of Lodz, Faculty of Law and Administration, Labour Law Chair, 90-232 Lodz, Kopcińskiego 8/12, Poland.

1 In fact, we can also meet with the concept of ageing old persons, older, elderly or persons that achieved retirement age, persons aged at $45+, 50+, 60+$.

2 See: A. Rycak, The common protection of the durability of the employment relationship, chapter II, point 2 in part. III, Lex 2013, No. 166604. 
The title of this paper signifies that the legal analysis is reduced to the protection guaranteed by the provisions of the Labour Code, leaving out other instruments and solutions intended to protect employment of elderly employees and save the existing jobs or create new ones ${ }^{3}$. This is so for the reason that discussion of employment relationship sustainability may also involve different notions with various meanings, e.g. permanence of employment, employment stabilisation, employment relationship stability, and protection of the right to keep a job ${ }^{4}$. However, the notion of sustainable employment is certainly closely related to the legal protection of jobs, since protection of employment relationship provides opportunity to work within the existing employment relationship ${ }^{5}$. At this point it feels right to distinguish between general protection, which is usually connected with control of the reasons for termination and applies to all employees, and special protection, which offers a wider range of protection and applies to employees who are found in exceptional personal or work situations for a certain period known as protection period ${ }^{6}$. From the perspective of elderly people, both types of employment protection deserve attention.

The recent changes in Polish legislation have been accompanied by evolution of the doctrines and jurisprudence. The revisions were caused by the need to adapt the applicable legal solutions to the ever changing conditions and social policies. Also, these changes reflect the European Union policies and regulations which are part of our legal system. The increasing average life expectancy of the population, on the one hand, and the demographic low underlain by various causes but also increasing, on the other hand, entail applying on the various employment levels special solutions adequately diversified to suit the older age. However, it is doubtless that legal regulations intended to protect sustainable employment, even if they are compatible with the interests of elderly employees, may collide with the interests of their employers and infringe on the interests of the unemployed, in particular the interests of young people ${ }^{7}$. Here, the conflict of interests of certain social groups, the young and the elderly, becomes evident, as the right to employment of the elderly clashes with the efforts to combat youth unemployment. Hence, reasonable as it is to review the sequence of changes, it is equally justified to consider the existing laws and regulations from the angle of their potential amendments.

3 See comments on the concept of protecting jobs and protecting the sustainability of employment relationship L. Florek, Protecting jobs and the interests of workers, employers and the unemployed, [in:] L. Florek (ed.), Labour law and unemployment, Warszawa 2003, p. 11.

${ }^{4} \mathrm{H}$. Szewczyk, Common protection of the durability of the employment relationship after the amendments to the Labour Code, [in:] Within the issues of labour law and social policy, vol. 13, Katowice 1998, p. 23, 24.

5 See also comments concerning narrow and broad understanding of the protection of the durability of employment relationship, with quoted representatives of doctrine, H. Szewczyk, op. cit., p. $25-27$.

${ }^{6}$ Compare H. Szewczyk, op. cit., p. 27, 28.

7 Ibid., p. 11-23, especially p. 22. 
Stabilisation of employment by protecting employment relationship of the elderly, who are within the group at particular risk of unemployment, is also indicative of the guarantee of a viable transition to retirement. If no restrictions on elderly employees' employment termination were in place, this would be very detrimental to them in the face of negligible job opportunities and high probability of losing the right to receive retirement pension that also depends on sufficient work periods ${ }^{8}$. The guarantee of employment stabilisation, being a demonstration of special protection, applies to employees in the pre-retirement age bracket, i.e. workers who are in the course of attaining the right to retirement pension. However, here arises a question about the extent of protection applicable to those elderly employees who are already eligible to receive retirement pension. Employees who have reached the retirement age are not subject to special protection, so their employment contracts may be terminated in keeping with the general terms and conditions that fall within the notion of general protection. However, it is unquestionable that those people may be very interested in staying in employment. With the present retirement system, the retirement age is no longer the key factor for persons considering application for retirement pension. Taking into account the fact that the basis for pension calculation is the value of registered premiums recorded on the insured's account. Reaching the retirement age has become less important than collecting an appropriate amount of premiums which are conditional upon employment periods and earnings 9 .

Also, it needs to be emphasised that legal protection, whether special or general, of employment sustainability, applies to persons who are employed on employment contracts, since employment on contracts other than employment contracts certain modifications to this protection may be considered, especially with respect to workers employed on the basis of nomination and cooperative employment contracts that may be terminated only after achieving the right to retirement pension ${ }^{10}$.

\section{Older employee as an object of protection}

The title of this paper mentions older employees. The criterion for distinguishing this category, therefore, is age, specifically older age. It is beyond doubt that the notions of an elderly or elder, older people as well as the elderly or old

8 Compare Z. Góral, Comment to article 39 of LC, [in:] K. W. Baran (ed.), Labour Code. Commentary, legal status as at 2012.04.15, WKP 2012.

9 See: J. Skoczyński, Retirement age as reason for termination of the employment contract, PiZS 2005, No. 4, p. 23-24.

${ }_{10}$ See about this: B. Wagner, Retirement age as the event of labour law, PiZS 2001, No. 3 , p. 26 . 
age may be understood differently, hence the meanings and the semantic scope of the foregoing notions could be different. The different meanings could be justified by diverse reasons that determine the use of these terms. Therefore, different meanings are given to these notions in medical, social, economic or legal sciences ${ }^{11}$.

As a legal category that appears in various law disciplines, age affects personal legal capacity, capacity to carry rights or obligations, and legal liability. On the other hand, as a source of social security law rights, age may also affect employee's situation ${ }^{12}$. Therefore, it is essential to set forth an age limit that will be the starting point from which employment of old persons will be protected. This poses a question about the semantic scope of the notion of an old person. First of all, the regulations of the Labour Code, which constitutes the main point of reference for this legal analysis, do not use that notion. However, they do refer to retirement age or, more precisely, in terms of employment protection they refer to employees who have no more than 4 years to go before they retire. Such workers are called employees in the pre-retirement period (Article 39 of the Labour Code $\left.(\mathrm{LC})^{13}\right)$. Hence, it seems justified to focus on those elderly employees who are included in or excluded from employment sustainability guarantees. Therefore, the considerations will oscillate around two categories of elderly employees, i.e. employees who have reached the pre-retirement age and employees who have reached the retirement age.

Before the Labour Code entered into force, protection against termination of employment contracts was not universal and could only be applied under the provisions of collective labour agreements. That state of affairs changed after the Chairman of the Ministers Council in 1960 issued a circular letter on Sole Wage-earners in Families concerning the specific guidelines and rules of lay-offs, which were not binding, but were to be taken into account when assessing compatibility of employment termination with the principles of social coexistence. Employees within the pre-retirement and retirement age bracket were one of the categories that were protected against termination of employment contracts ${ }^{14}$.

11 There is no way to even discuss in part the views expressed in the literature with regard to the proposed definition or attempts to reconstruct these definitions due to multithreading issues and limited framework. More about this B. Mikołajczyk, International protection of the rights of the elderly, WKP 2012, Lex, No. 156494.

12 See: B. Wagner, op. cit., p. 20.

13 Labour code of 26 June 1974, OJ 1 199, No. 21, item 94 consolidated text with amendments.

14 The employer should not have to terminate the employment contract of employee who archived the so-called old age. Another example of policy guidelines for employees dismissals was Central Trade Union Council's circular of 5 October 1961 on protection against dismissals for only family providers and workers that achieved retirement age, but who do not have a pension. Accordingly to this, the rules applied to abovementioned employees should be considered as the principles of social justice and the violation of these principles made dismissal, accordingly to article 41 of civil law, ineffective. See about it A. Rycak, The universal protection of the durability of the employment relationship, part. I, 2 in. (II), Lex 2013, No. 166604. See also: B. Wagner, op. cit., p. 22. 
After the Labour Code entered into force, by virtue of Article 39 protection was granted to employees who had not more than 2 years to go before reaching the retirement age, if the length of service entitled them to retirement pension after reaching that age. Also, the pre-retirement age that delimits the period of protection, was understood as the age that predates the right to become eligible for retirement pension ${ }^{15}$.

Unquestionably, retirement age is a notion typically used in the field of social security law, where it appeared for the first time in the provisions of the Act of 23 January $1968^{16}$ and replaced the notion of the "elderly age" used in legal provisions until that time ${ }^{17}$. This change should be certainly recognised as positive. The notion of the old or elderly age, without any doubts, sounds quite pejoratively. In contrast, the term 'retirement age' is identified with appropriate experience or length of service, rather than old age and disability.

Talking about retirement age, we could mean general retirement age, reduced retirement age, or earlier retirement age ${ }^{18}$. Therefore, a question arises which kind of retirement age is used in the Labour Code. Article 39 of LC does not explain this issue, referring to an employee who has not more than 4 years to go before retirement. It is worth pointing out here that the extension of the protection period from 2 up to 4 years resulted from the amendment of Article $39^{19}$. However, the four-year protection only applies to those employees whose length of service entitles them to retirement pension after reaching that age. What should be highlighted, too, are certain differences in legal regulations that apply to employees employed on the basis of nomination. Under the provisions of Article 72(3) of LC, employment of an employee who has not more than 2 years to go before becoming eligible for retirement pension from the Social Security Fund (SSF) ${ }^{20}$ may be terminated, but the dismissing authority has the duty to offer that employee another job that corresponds to his/her professional qualifications, where such an employee is entitled to remuneration in the amount due prior to the dismissal from office for a period equal to the period of notice.

General retirement age, also referred to in literature as "regular" or "usual", now means the age of 67 which at present applies to employees of both sexes ${ }^{21}$.

15 Compare B. Wagner, op. cit., p. 23.

16 The law on Common social security for employees and their families, OJ 1968, No. 3, item 6.

17 On the basis of art. 28 and n. of the Decree of 25 June 1954 for Common social security for workers and their families, OJ 1954, No. 30, item 116 was talking about the right to old age pension for people of senile age with appropriate period of employment.

18 See: B. Wagner, op. cit., p. 21 and J. Skoczyński, op. cit., p. 23. This also indicates M. Łajeczko, K. Tymorek, Preretirement age protection of employees, SP 2000, No. 3, p. 1-4.

19 From 1 January 2004.

20 Social Security Fund.

${ }^{21}$ Until the end of 2012, the age was diversified and stand at the level of 60 years for women and 65 for men. 
Retirement age was changed under the provisions of the Law of 11 May 2012 on amending the law on pension benefits and disability pension benefits from the Social Security Fund and certain other laws ${ }^{22}$, effective as of 1 January 2013, which resulted in gradual increase of retirement age. Gradual monthly increases of retirement age take place at the end of the subsequent quarters of the calendar year ${ }^{23}$. This solution means that retirement at the age of 67 years will apply to men in 2020 , 8 years after the law came into force, and to women in 2040, i.e. after 28 years $^{24}$.

Moreover, we should also remember about Article 18 of the aforementioned amending Law, under which employees who upon the effective date of that Law were covered by employment protection provided by Article 39 of the Labour Code, or employees who could be covered by such protection, if they were in employment at the time, are protected against termination until they reach the retirement age specified in the regulations within Article 24(1a) and (1b) and Article 27 (2) and (3) of the $\mathrm{Law}^{25}$. Consequently, this leads to extension of the period of protection in respect of some employees. It is aptly noticed that if no transitory provisions have been introduced, this would cause the employees, who upon the effective date of the amending Law were covered by special protection to gradually lose protection over a period from 3 months to 4 years ${ }^{26}$.

Retirement age may also mean reduced retirement age which is lower than general retirement age ${ }^{27}$. This is about a certain lower retirement age limit that is applicable to specified groups of employees doing specific jobs or working under special conditions. For certain groups of employees, this reduced retirement age is their regular retirement age. Hence, job protection is also offered to employees in the pre-retirement age bracket. For quite a long time, however, dominant was the opinion that special protection did not cover employees entitled to earlier retirement. This was also confirmed by judgments of the Supreme Court (SC). At that, the SC Resolution of 12 May 1976 and its later judgments, including

22 OJ from 2012, 637.

${ }_{23}$ Compare K. Jaśkowski, Commentary to article 39, article 40 of the Labour Code, the legal status on 2014.06.15, Lex/el 2014, No. 174694.

${ }_{24}$ Pursuant to article 3 of this Act retirement age at 67 years will be applicable to women born after September 30, 1973 (retirement age shall be at least 60 years for women born in the period up to 31 December 1952) and men born after September 30, 1953 (retirement age of at least 65 includes men born before 31 December 1947). See: K. Antonów, Commentary to art. 24 the law on Pensions from Social Security Fund. Commentary, the legal status for 2014.04.15, Lex 2014, No. 172025.

${ }_{25}$ Hence workers who on 1 January 2013, were covered by the protection of relationship resulting from the article. 39 of LC (or they could be subject of it, if that day remained in the employment relationship), retain this protection by the time until retirement age referred to in article 24 section $1 \mathrm{a}$ i $1 \mathrm{~b}$, that will result in the extension of the temporary 4-year period of protection (from one month to one year and 4 months) for certain employees: women born from 1 January 1953 to 31 December 1956 and men born from 1 January 1948 to 31 December 1951. See: K. Antonów, op. cit.

26 See: K. Jaśkowski, op. cit.

27 Governed by the provisions of article $32-45$ of the pensions ordinance. 
the SC judgment of 12 March 1991 deserve special attention. Pursuant to the latter, employees who were eligible for earlier retirement were not protected, because the cases of earlier retirement - outside the general retirement age scheme - were treated as a kind of social privilege, regardless of the nature of the work, whether difficult or carrying health hazards. It was aptly noticed, however, that there existed no strong arguments to justify exclusion of job protection of employees, whose reduced retirement age was not a privilege ensuing from factors other than employment, but from the conditions strictly linked to the nature of their jobs. Subsequently, this was the general direction taken in consecutive judgments of SC ${ }^{28}$. The judgment of 11 July 2007, III PK 19/07 explicitly emphasised that the lower-than-general retirement age of workers employed under special conditions or performing special jobs is in fact their regular statutory retirement age, which in turn causes such employees to enjoy special employment protection within Article 39 of LC over the period of 4 years before they reach the retirement age that is appropriate for these categories of employment. That interpretation was also confirmed in other judgments, i.e. the judgment of SC of 8 July 2008, I PK 309/07, judgment of 9 March 2009, I PK 180/08, and judgment of SC of 19 April 2010, II PK 311/09. Pursuant to the judgment of 6 December 2012, I PK 145/1229, employment protection provided by Article 39 should be applied to employees who have not more than 4 years to go before they reach the age entitling them to the bridge to retirement, provided that once they have reached that age they will become eligible for retirement pension. However, these employees cannot regain the right to protection in case they reach general retirement age, otherwise they would be protected for an extended period of 8 -years'.

It is necessary to distinguish general and reduced retirement age from the right to earlier retirement, which entitles the persons covered by the relevant regulations to receive their pension earlier. In terms of Article 29 of the Law on Pension and Disability Pension Benefits from SSF, the insured that were born before 1 January of 1949 who have not reached the retirement age specified in Article 27(2) and (3), may retire: in case of women - having reached the age of 55, if their premium and

28 Consequently, in the judgment of 28 March 2002, PKN 141/01, court assumed that protection provided by article 39 of LC also includes workers employed in particular conditions or specific character during the 2 years period before reduced retirement age ( 2 years period was in an earlier version of this provision) if the period of employment enables them to obtain the right to pension reaching a lower retirement age. Likewise, SC ruled in respect of specific occupational group. So in the judgment SC of 29 July 1997, PKN $227 / 97$ stated that the retirement age within the meaning of article 39 of LC for railway employees stands at 60 years for men. Following the judgment of the SC of 5 February 2004, and PK 348/03, the retirement age entitling miners to retirement pension is the age within the meaning of article 39 of LC This line has been retained after the amendments to this article 39 of LC, providing for employees protection the period of 4 years before retirement age. Compare Z. Góral, Commentary to article 39 of LC, [in:] Labour code...

${ }^{29}$ Lex, No. 1284682. 
non-premium periods are at least 30 years, or at least 20 years and they have been recognised as completely unable to work, in case of men - having reached the age of 60 years, if their premium and non-premium periods are at least 35 years, or at least 25 years and they have been recognised as completely unable to work. The right to earlier retirement does not protect employees eligible for earlier retirement against dismissal, because earlier retirement is the of the insured which they may or may not exercise ${ }^{30}$. Therefore, there is no sustainable employment for such persons during the four-year period predating the said earlier retirement. In the judgment of 16 July 2008, I PK 11/08, SC also ruled that protection within Article 39 does not apply to eligibility for pre-retirement benefit.

The solution within Article 72 of LC refers to the 2-year period prior to becoming eligible for retirement pension from SSF. This formulation could suggest that the regulation is inclusive of all cases in which employee may become eligible for retirement pension and benefits, including earlier retirement. This interpretation, however, was overruled by the SC in its judgment of 9 February 2006, II PK 159/05, where it stated that protection within Article 72 (3) in conjunction with Article 72(2) of the LC does not apply to the right to earlier retirement within Article 29 of the Law on Pension Benefits ${ }^{31}$.

Protection of sustainable employment of employees in pre-retirement age bracket is subject to certain exclusions and modifications. Article 39 of LC will not apply to an employee who has become eligible for disability living allowance on the ground of total incapacity to work (Article 40 of LC) ) $^{32}$. In terms of Article 12 of the Law on Pension and Disability Pension Benefits from SSF, a person is completely incapable to work if they have lost the ability to perform any kind of work. This means that protection will not be excluded in respect of persons receiving disability living allowance due to partial incapacity to work. In terms of the judgment of 18 January 2012, II PK 149/1, protection against termination of employment contract within Article 39 is only excluded in respect of such persons, whose right to disability living allowance due to their total incapacity to work has been confirmed by the order of a competent authority (Article 40). However, legal literature presents disparate standpoints, too, where the right to disability living allowance suffices to exclude employment protection ${ }^{33}$. The amendment to Article

30 See: M. Zieleniecki, Commentary to article 29 of the Act on Pensions from Social Security Fund, Commentary, the legal status for 2014.04.15, Lex 2014, No. 172025.

31 See: Ł. Pisarczyk, Commentary to article 72 of LC, [in:] L. Florek (ed.), The Labour Code. Commentary, legal status for 2011.05.16, Lex 2011, No. 104447.

32 Within the previous version, article 39 couldn't be applied in the event of an employee's right to invalidity pension for I or II group of disabled persons. Replacing the notion of invalidity groups by partial or complete incapacity for work was justified by the changing of rules under the Act from 2002 of 26 July 2002 amending the law - the Labour Code and other acts, OJ, No. 135, item 1146.

33 Shows this Z. Góral, Commentary to article 40 of LC, [in:] Labour code... 
40 of LC, which had previously excluded applicability of the regulations within Article 38 of LC in the event when employee had achieved the right to disability living allowance for being classified as disabled in the $1^{\text {st }}$ or $2^{\text {nd }}$ degree, nevertheless means that employment termination for this reason is subject to consultation with the trade union ${ }^{34}$.

\subsection{Scope of protection of sustainable employment of elderly employees - changes in legal regulations and evolution of the outlook of the doctrine and jurisprudence}

The scope of protection of sustainable employment of elderly employees is very important, too. As has been mentioned before, this protection varies between employees in the pre-retirement and retirement age brackets.

Polish legislature offers special treatment to employees in the pre-retirement age bracket, where, as has been mentioned herein above, this applies to persons eligible for retirement upon reaching general or reduced retirement age, as long as upon reaching retirement age they acquire the right to retirement pension under national insurance ${ }^{35}$.

Protection within Article 39 should be classified as a time-limited absolute protection ${ }^{36}$. This is so because it encompasses prohibition to terminate employment contracts with persons being in the protection period. Therefore, termination of employment contract prior to the protection period is legally admissible. The legality of such termination will not be affected by the circumstance that in the course of the notice period employee will have entered the protection period. This is so because employer cannot terminate employment contract only during the protection period, while the ensuing termination itself may become effective during the protection period, if the termination notice is given earlier.

Thus, the scope of protection of employees in the pre-retirement age bracket is reduced to prohibition of giving the contract termination notice, but does not exclude the option of terminating employment contract with immediate effect. It should be highlighted that the said prohibition applies not only to final termination, but to terminations with notice amending the terms and conditions of work or pay as well. By way of an exception, the legislature allows to terminate on notice revising the terms and conditions of work or pay, if the requirements set forth in

${ }^{34}$ See: L. Florek, Commentary to art. 40 of LC, [in:] Labour code...

35 Therefore, it was pointed out that article. 39 of LC should be treated as provisions that protect workers approaching retirement age, but as article that protects the employment stability in the period before achievement the right to retirement pension, treating this protection as conditional because of dependence from right to pension. See: B. Wagner, op. cit., p. 23.

36 It also occurs in the literature under the term of protection of the third degree, see. A. Dubowik, Special protection against termination of employment relationship, PiZS 1997, No. 3, p. 24. 
Article 43 of LC are met ${ }^{37}$. Furthermore, Article $241^{13}$ of LC must be taken into account, too, as it allows to terminate with notice revising the contractual terms and conditions so as to implement less favourable provisions set forth in the new contract. This excludes applicability of the regulations that restrict the right to terminate the terms and conditions of employment contract or any other instrument that creates employment relationship ${ }^{38}$.

Protection of sustainable employment of older employees in the pre-retirement age bracket is also excluded in case of bankruptcy or winding-up of employer. Today it goes without saying that protection guarantees prevail in case of bankruptcy with composition option, as well as when employer winds-up upon takeover ${ }^{39}$. Protection of sustainable employment of employees in the pre-retirement age bracket has been modified in respect of dismissals on the grounds of the regulations of the act on layoffs for reasons not attributable to employees, where in case of collective or individual dismissals contracts may be terminated with notice revising the terms and conditions of work or pay ${ }^{40}$.

Quite different is the situation of older employees who are reaching retirement age. In their case special protection (Art. 39 of LC) is excluded, which makes them eligible for general protective guarantees that are part of the general sustainable employment protection ${ }^{41}$. Therefore, the legal situation of older employees reaching retirement age deserves a closer analysis to address the question about the right to work after reaching retirement age ${ }^{42}$. The right to work while concurrently receiving retirement pension has also been recognised as a key issue in earlier publications ${ }^{43}$. It is no wonder, then, that the legal solutions we experienced several years ago and which made the right to retirement pension conditional upon terminating the employment contract were treated as compatible with the principles of social justice ${ }^{44}$.

37 Among them are indicated: introduction of new terms and conditions of remuneration applying to all employees of that employer, or to a group of employees to which that employee belongs, as well as incapacity to perform certain work, confirmed by medical certificate.

38 Compare Z. Góral, Commentary to article 43 of LC, [in:] Labour code...

39 See judgment from 4 April 2007, III PK 1/07, resolution of 16 March 2010 r., I PZP 1/10 and judgement from September 2008 r., II PK 44/08.

40 Article 5 paragraph 5 p. 1 and art. 10 of the Act. It should be noted at this point that law introduces the admissibility of termination of employment contracts concluded for a specified period, that are couldn't be terminated in principle, by two-week period of notice.

41 The same point presents J. Skoczyński, op. cit., p. 21.

42 See: Z. Hajn, Right to work beyond retirement age, Folia Iuridica, 58, 1993, p. 39 and Admissibility of the termination of employment contract accordingly to retirement age or entitlement to a retirement pension, [in:] Z. Góral (ed.), Anniversary Book for Prof. H. Lewandowski, p. 278-279 and points of the other authors indicated therein. On retirement age as a reason justifying the termination indicates also B. Wagner, op. cit.

${ }^{43}$ See: W. Szubert, Social insurance. Overview of the system, Warsaw 1987, p. 165 and n.

${ }^{44}$ See: idem, p. 167. 
In the pre-war legal system, pensions granted due to old age were treated as disability benefits, which caused old age itself to be identified with the disability ${ }^{45}$. In the pre-Labour Code period protective regulations were correlated with retirement regulations. Employers had the right to decide about the retirement of employees, which was done by terminating employment contracts in the legally prescribed manner. Hence, eligibility for retirement pension was treated as the legal reason for terminating employment contract ${ }^{46}$.

After the Labour Code entered into force, the then binding Article 39 in conjunction with Article 40 gave rise to disparate standpoints both in judicature and labour law doctrine. Article 40 Section 2 of LC which excluded the duty of consulting the trade unions with regard to the reason for termination in the case of employees reaching retirement age was interpreted as a provision that entitled employers to terminate employment contracts for the reason of them having reached retirement age $^{47}$. Even though this was the prevalent standpoint, on the grounds of the contemporary legal system disparate opinions were voiced, too ${ }^{48}$. The changes in the interpretation of this provision were brought about by the amendment of 2 June 1996 by virtue of which the aforementioned section 2 of Article 40 of LC was deleted ${ }^{49}$. According to some, the deletion of this regulation was construed as an exclusion of retirement age from the notion of good reason for termination of employment contract, in recognition that otherwise consultations with the trade unions would be completely pointless ${ }^{50}$. Others, however, were of the opinion that the amendment still justified recognising retirement age as a good reason for termination of employment contract, but even more than retirement age itself, that good reason was the right to retirement pension, in recognition that the said amendment aimed to change the general control of employment contracts termination ${ }^{51}$.

The SC resolution of 27 June 1985, III PZP 10/85, determined the guidelines concerning the interpretation of Article 45 of LC, where retirement age was recognised as a good reason for termination of employment contract. According to the SC, retirement age was to be understood as the age prescribed in the retirement regulations and making employees eligible for retirement entitlements within the regular procedure. Despite the severe criticism of the Supreme Court's

45 More about this W. Szubert, op. cit., p. 108.

46 See about it: B. Wagner, op. cit., p. 22. Noteworthy is also the Act of 15 July 1968 on Employees of national councils, that introduced admissibility of the termination of employment contract only in specific cases and the one of them was the achievement of the right to pension.

47 See: Z. Hajn, op. cit., p. 44-46.

48 The authors that presents dissent points shows Z. Hajn, op. cit., p. 278.

49 OJ, No. 24, item 110.

50 See: W. Sanetra, The retirement age as a cause of termination, PiZS 1997, No. 6, p. 22; M. Skąpski, Retirement age as the reason for termination of the employment contract, PiZS 2001, nr 3, p. 21.

51 See: W. Sanetra, op. cit.; Z. Hajn, The Admissibiliy..., p. 280; B. Wagner, op. cit., p. 22. 
standpoint, it was rather consistently, though with some modifications, emulated by other courts and the doctrine ${ }^{52}$. Interestingly, however, in light of the said guidelines the situation of re-employed pensioners appeared disparate, as in case of their dismissal it was necessary to provide a good reason for employment termination. The Supreme Court, however, recognised employment of a younger or fully fit person to be a good cause for employment termination ${ }^{53}$.

The standpoint that retirement age provides the grounds for termination of employment contract was quite consistently sustained in subsequent judgments of SC. For example, in the judgment of 10 April 1997, SC found that reaching retirement age may be an intrinsic reason for termination, in turn in the judgment of 21 April 1999, SC decided that termination of employment contract for reason that a woman has reached retirement age (60) and is eligible to receive retirement pension is legitimate and may not be deemed as discrimination on the grounds of sex or age (Article $11^{3}$ of LC). SC adopted a similar standpoint in its order of 18 July 2003, I PK 210/03.

Retirement age was approached in a similar fashion also in later decisions of SC, e.g. the judgment of 26 November $2003^{54}$, I PK 616/02, and the judgment of 29 September 2005, II PK 19/0555. However, disparate interpretations were formulated, too. For example, in its judgment of 15 October 1999, I PKN 111/99, $\mathrm{SC}$ ruled that eligibility for earlier miner's retirement does not intrinsically justify termination of employment contract. The later amendment to the Labour Code of 2 February 1996, by virtue of which section 2 of Article 40 of LC was deleted, did not bring about a definite change of direction in its interpretation.

A significant change of the Supreme Court's viewpoint, certainly inspired by the judgments of the European Court of Justice, took place in the judgment of 19 March 2008, I PK 219/07 which stated that termination of employment contract, if solely justified by a woman's eligibility to receive rail pension at the age of 55, violates the prohibition of discrimination on the grounds of sex within Article $11^{3}$ of LC. A similar viewpoint was adopted in the SC resolution passed by a chamber of seven judges on 19 November 2008, I PZP 4/08. But a real breakthrough in the interpretation occurred as a result of the resolution adopted by a chamber of 7 SC judges on 21 January 2009, II PZP 13/08. The Supreme Court's standpoint was developed with reference to European law and judicature. The Supreme Court decided that retirement age and eligibility for retirement pension are not relevant

${ }_{52}$ Indicates this Z. Hajn, Right to work beyond ..., p. 45 and n. See also: W. Sanetra, op. cit.

53 See the justification of judgment contained in IV point.

${ }_{54}$ According to it, the achievement by the employee retirement age is an independent reason justifying termination of the employment contract and is not a manifestation of discrimination against the worker who has acquired the right to a pension.

${ }_{55}$ The achievement by the employee the right to pension is a reasonable cause for employment contract (concluded for indefinite period) termination (article 45 section 1 of LC); that does not mean discrimination against employees on the ground of their age (article 11section 3 of LC). 
to work and, therefore, cannot be an intrinsic reason for employment termination with notice. It is, therefore, necessary to quote objective reasons attributable either to employee or employer ${ }^{56}$.

Nevertheless, retirement age can be looked at from a different angle as a criterion for selecting an employee to be dismissed in the event of redundancies for economic reasons, especially when eligibility for retirement pension may be a convincing argument for keeping in employment an employee who has no such source of income ${ }^{57}$. However, reference to employer's right to implement his own employment policy must be approached differently. According to SC, retirement age is a socially justified criterion for selecting redundant employees and, what follows, cannot be deemed as a criterion that discriminates a specific group of employees - the judgment of 14 January 2008, II PK $102 / 07^{58}$. A similar viewpoint was expressed in the judgment of 25 July 2003, I PK 305/02.

At this point it is by all means reasonable to consider the cases of termination of employment contract with employees who have reached retirement age and become eligible for retirement pension, frequently referred to as "automatic termination of employment contract" or "compulsory retirement". The recent changes in the legislation must certainly be recognised as positive. In part, they were informed by implementation of the regulations prohibiting discrimination on the grounds of age, increased retirement age, and in other cases, by exclusion of the duty to retire ${ }^{59}$.

However, still in force are regulations that envisage termination or expiry of employment contract with a certain category of employees. The forced distribution of employment opportunities may give rise to controversies, especially in the face of the danger of permanent withdrawal of elderly people from the labour market ${ }^{60}$. This is claimed to be justified by the generational change on the labour market and reasonable need to "ration rare goods", such as jobs ${ }^{61}$. In that light,

56 See: Z. Hajn, Admissibility of..., p. 285.

57 See: ibid., p. 286. About this see also judgement of SC from 3 December 2003, PK 80/03, OSNPUSiSP 2004, No. 21, item 363. See also justification to the resolution of the SC from January 21, 2009, (II) PZP 13/08, underlining that singling out (selection) for dismissals employees who after the termination of the employment contract will have retirement benefits is socially justified, compatible with social principles and couldn't be treated as discrimination because it allows to stay at work for those who are not entitled to benefits from social security.

58 Lex, No. 437024.

59 This confirms the amendments made in the following laws: art. 13 sec. 1 p. 5 law of 16 September 1982 r. on Public Service Employees, art. 41 sec. 2 p. 1 law of 24 August 2006 r. on Civil Service, art. $93 \mathrm{sec} .2$ p. 1 law of 23 December 1994 r. on Superior Audit Office, art. 62 sec. 1 p. 7 law of 13 April 2007 r. on Labour Inspection.

${ }_{60}$ The abovementioned doubts and problems indicates G. Orłowski, To give way (work) for the younger, MPP 2011, No. 6.

${ }^{61}$ See also comments made by B. Mikołajczyk, The retirement age in cases before the Court of Justice. The problems of contemporary international, european and comparative law, Vol. X, A.D. MMXII, p. 10. 
retirement of older employees reaching retirement age becomes socially justified and gives ground to moral arguments expressed by the principle of non-discrimination on the grounds of age ${ }^{62}$. This, however, only applies to special categories of employees.

This can be exemplified by the following regulations. Article 127 of the Law of 27 July 2005 on Higher Education ${ }^{63}$ specifies the cases of expiry of employment contract of nominated teacher by virtue of law and stipulates that employment relationship with academic teacher employed by a public university expires at the end of the academic year in which the teacher has reached the age of 67, if the teacher has become eligible for retirement pension ${ }^{64}$. Likewise, employment relationship of nominated researcher employed by research facilities or other organisational units of the PAN [Polish Academy of Sciences] as an associate professor or professor, expires at the end of the year in which the employee has reached the age of $70^{65}$. However, the position of employees of the National Audit Office is different following the deletion of Article 93(2)(1) of the Law on Supreme Audit Office ${ }^{66}$ which contemplated termination of employment contract without notice as a result of employee reaching the age of 65 and becoming eligible for retirement pension from the Social Security Fund ${ }^{67}$. The change was informed by the increase of retirement age as of 1 January, 2013.

The influence of retirement of age on the situation of teachers employed under the provisions of Teachers' Charter Law $^{68}$ looks a bit different. By virtue of the Law of 23 November 2012 on amending certain laws in connection with the raise of retirement age ${ }^{69}$ overruled were the provisions that required to terminate employment contract with nominated teachers who have reached the age of $65^{70}$. Until 21 October 2001 taken into account was not the age limit, but rather

62 Compare G. Orłowski, op. cit.

63 OJ 2012, No. 572 , c.t.

${ }_{64}$ Act of 23 November 2012 changed the retirement age of 65 years. It was raised due to changes in pension law. If the age of 67 year will entitle to retirement pension, the termination of employment contract will take place following the end of the academic year in which employee will acquire this right. In turn, the employment contract with Professor expires at the end of the academic year in which he achieves 70 year of life.

65 Article 102 of the Act of 30 April 2010 on Polish Academy of Sciences, OJ 2010, No. 96, item 619 with amend. amend.

${ }_{66}$ The Act on Supreme Control Chamber of 23 December 1994 r., OJ 2012, 82, c.t. with

67 Under the Act of 23 November 2012, OJ 2012, 1544.

68 The law from 26 January 1982, Teacher's Card, OJ 2014, 191, c.t. with amend.

69 OJ from 2012, item 1544.

70 The equalizing of age for termination of employment contract was the consequence of pronounced discrimination on the grounds of sex and occurred as a result of the judgment of the CC of 28 March 2000, K 27/99, OTK 2000, No. 2, item 62. Accordingly to the previously applicable law the employment relationship with the teacher employed on the basis of the appointment was terminated at the end of the school year in which the teacher has achieved 65 years. 
eligibility to retire for having reached retirement age, as set forth in the regulations on retirement benefits of employees and their families (this provision was rescinded by the law of 23 August, 2001 ${ }^{71}$ ). In such a case, employer was obliged to terminate employment contract at least 3 months before the end of the school year $^{72}$. If teacher was not eligible for retirement pension at the age of 65 , their term of employment could have been extended for the maximum of 2 years after reaching that age ${ }^{73}$. Following the aforementioned changes (in force as of 1 January 2013) it will not be possible to terminate employment relationship with teachers for the sole reason of their eligibility for retirement entitlements ${ }^{74}$.

Another issue that also needs to be considered here is the Law on the System of Courts of General Jurisdiction ${ }^{75}$ which specifies the maximum age upon which judges retire. Article 69 of that law provides that judges shall retire at the age of $67^{76}$, unless not later than six months prior to turning $67^{77}$ they deliver to the Minister of Justice an expression of interest in staying in office and submit a medical certificate confirming their ability to perform judicial duties that has been issued in keeping with the rules specified for candidates for judicial positions ${ }^{78}$. It has been noted that this regulation, with regard to the retirement age limit, may raise doubts, as it provides no reason for the age limit so defined which, once reached, would entail retirement ${ }^{79}$. At that, it is indicated that as a rule judges should stay in office until the age of 70, and only upon request could they retire at 67 , as has been adopted in the case of judges of the Supreme Court. In terms of Article 30 of the Supreme Court Act ${ }^{80}$, Supreme Court judges retire at the age of 70, and only upon request can they retire at 67 . Hence, the Supreme Court Act lays down

${ }_{71}$ OJ, No. 111, item 1194.

72 The termination at the end of the school yeas wasn't applied to the teachers employed in schools, which does not provided school holidays.

73 See: M. Szymańska, Commentary to art. 23 of the Act on Teacher Card, [in:] Teacher's Card. Commentary, Lex 2012, legal status 2012.05.01, No. 126255.

74 This is connected with article 88 of Card, providing the possibility for teachers to retire regardless of age, by their request on condition of the required employment period.

75 Act of 2013 , it. 427 , c.t. with amend.

76 The change related to the raising of retirement age.

77 The Act of 11 May 2012, amended the law on pensions and certain other laws (OJ 2012, item 637), which entered into force on 1 January 2013 giving the new wording of article 69 section 1 , replacing the date of age of 65 years by 67 years of age.

78 After conditions fulfillment, referred in section 1, the judge may perform work but no longer than until 70 years of age. The judge may at any time be retired on the base of his own request declared to the Minister of Justice.

79 In the past, this limit was higher and, for example, under the rule of the law on Courts system from 1928, judge was retired when he achieved 70 years, and for the judges of the Supreme Court, this period could be extended up to 75 years old - see about it P. Dąbrowski, A. Lazarska, Commentary to art. 69 of the Act on Courts system, [in:] A. Górski (ed.), The law on Courts system. Commentary, legal status, Lex, 2013.06.30, No. 152626.

80 Ibid. 
the rule that Supreme Court judges reach retirement age at 70 and do not have to document their health condition with medical certificate. Also questioned is the duty to submit medical certificates by judges of courts of general jurisdiction, in recognition that in case of any doubts concerning a judge's ability to perform their duties the court college may require to provide an appropriate certificate. It is also highlighted that lowering this age limit is not reasonable, the more so that over the last century the average life expectancy has increased. Nevertheless, the postulate of life-long service of judges, unless prevented by health condition, can be deemed controversial ${ }^{81}$.

The length of service is regulated likewise by the Prosecution Service $\mathrm{Law}^{82}$. However, courts have had to be involved to resolve the issue of some fundamental changes to the right to work of prosecutors, once they have reached the prescribed age limit, which will be discussed further herein. Pursuant to Article. 62a, prosecutors may stay in office, if the General Prosecutor grants such consent upon request from the applicant and against favourable medical certificate and following consultations with the applicant's superior.

With regard to legitimacy of employment contract termination for reason of employee reaching the prescribed age limit, an important role is played by EU regulations and judicature of the European Court of Justice (ECJ) concerning equal treatment of employees and non-discrimination on the grounds of age. Importantly, the number of ECJ judgements in this respect is growing by the year. Also, they inform how EU laws and regulations are interpreted by Polish legislature. The solutions adopted are basically warranted by the need for generational replacement at work, or for sharing employment opportunities between generations $^{83}$. Generational replacement, as the reason for refusal of further stay in office, is also more and more commonly claimed by Polish body of final appeal which relies on the judgements passed by ECJ. Examples of this include SC judgements concerning sustainability of employment of older prosecutors, e.g. the SC judgment of 13 May 2010, III PO 1/10 $0^{84}$, in which generational replacement at work was treated with much reserve, and the judgment of 14 January 2010, III PO $7 / 09^{85}$, in which it was ruled that good health and intention to wait until the $45^{\text {th }}$ anniversary of professional career, as well as work satisfaction, or sharing professional experience with the younger generation of prosecutors may not be recognised as the grounds which automatically support further stay on the prosecutor's job. In the reasons for the judgement it was argued that the General Prosecutor's

81 The Act of 23 November 2002 r., OJ 2013, 499, c.t. with amend.

82 P. Dąbrowski, A. Łazarska, Commentary to article 69.

${ }^{83}$ It is often the main point for justification of retirement age (if it connected with the right to pension) as a criterion leading to termination of employment relationship, used by Court of Justice of the European Union.

${ }^{84}$ Lex, No. 1086917.

${ }^{85}$ Lex, No. 578147. 
decision cannot be informed by the abstract notion of "generational replacement of prosecutors", but by needs and conditions of HR policy related to the actual situation in the given prosecution service unit. Hence, the General Prosecutor stands committed, within the authority granted under the said regulation, to consider all the circumstances or interests. At this point it feels right to bring to attention the judgment of 24 January 2012, III PO 7/11 ${ }^{86}$, and the judgment of 14 February 2012, III PO 8/1 ${ }^{87}$, pursuant to which generational replacement of prosecutors is a reason which the General Prosecutor may take into account while assessing whether the prosecutor's request concerning further the stay in office is really justified.

The rule of no age discrimination in employment is laid down by the Council Directive no. 2000/78/EC of 27 November 2000 which lays down the general framework of equal treatment in employment and work. However, Article 6(1) provides that Member States may provide that differences of treatment on grounds of age shall not constitute discrimination, if, within the context of national law, they are objectively and reasonably justified by a legitimate aim, including legitimate employment policy, labour market and vocational training objectives, and if the means of achieving that aim are appropriate and necessary ${ }^{88}$. The Tribunal emphasises the freedom of Member States in choosing the appropriate measures of differentiation ${ }^{89}$.

Article 2(5) of the Directive also deserves attention at this point ${ }^{90}$. Retirement age may justify different treatment with regard to continuing employment, if that entailed taking measures necessary to ensure public security, protection of health, rights and freedoms of other persons. In this respect a close relationship with biological aging of human body is certainly present here. But also this circumstance may not always justify employment contract termination. In the ECJ judgment of

86 Lex, No. 1129352.

87 Lex, No. 1171292.

88 Article 6 section 1 of Directive cannot be interpreted as permitting under any circumstances termination of employment due to achievement by the employee the right to old age pension. On the contrary, it is clear that to terminating of employment contract due to retirement age and acquisition of pension violates the prohibition of discrimination on grounds of age, if it was not justifiable circumstances provided in it. See also justification to the resolution of the SC from January 21, 2009, op. cit.

${ }^{89}$ This means, that there will be substantial differences in the law regulations of the Member States will, causing that the retirement age as the cause of the termination of the employment contract in one country will be considered to be compatible with the directive, while in the other will be treated as unreasonable criterion of differentiation. See: M. Tomaszewska, Commentary to the judgment of the ECJ on the C-411/05, GSP-PO 2009, No. 1, p. 163.

${ }_{90}$ This Directive shall be without prejudice to measures laid down by national law which, in a democratic society, are necessary for public security, for the maintenance of public order and the prevention of criminal offences, for the protection of health and for the protection of the rights and freedoms of others. 
13 September $2013^{91}$ the Tribunal analysed whether the retirement age prescribed for airline pilots automatically leads to termination of employment contracts. In the judgment it was found that the age limit of 60, prescribed for airline pilots as the limit of their licence to practice the profession, does not warrant prohibition of practising the profession, but rather its possible limitation ${ }^{92}$. In terms of Article 101 of Polish Aviation Law ${ }^{93}$ licensed aircraft or airline pilot who has reached the age of 60 cannot pilot international flights, unless he/she is a member of several-strong crew, or is the only crew member who is 60 years old, while licensed pilot, as described in sec. 1, who has reached the age of 65 may pilot an aircraft used in air transport. The amendment of 1 January, 2013 overruled the provisions of sec. 3 which prohibited licensed air controllers from practising the profession at the age of 60 .

Recognition of retirement age as a good reason for automatic termination of employment contract appears to raise serious doubts. The assessment whether we are dealing with discrimination or justified disparate treatment on the grounds of age depends on whether the conditions set forth in Article 6(1)(a) are met cumulatively. In the opinion of ECJ, employment support is an unquestionably justified aim of social or employment policy of member states ${ }^{94}$. A number of ECJ judgments appear to make this point. ECJ recognises that a measure intended to promote access of young medical professionals to the profession of a dentist within the system of health insurance may be an example of a regulation representing a justified employment policy measure ${ }^{95}$. Likewise, compulsory retirement of prosecutors (at the age of 65) was also found compatible with the directive, inasmuch the aim of the national law was to establish a favourable age structure in order to further recruitment and promotion of young people, improve human resources management and, thereby, prevent possible disputes concerning employees' fitness to work beyond a certain age ${ }^{96}$. Also, in the Rosenblad case, ECJ stated that national regulations which provide for automatic termination of em-

${ }_{91}$ In case C-447/09, R. Priggie, M. Fromm i V. Lambac p. Deutsche Lufthansa AG (Lex, No. 898237).

92 See: par. 73 in case C-447/09: it was underlined that, both national and international legislation provide that pilots may continue to carry out their activities, under certain restrictions, between 60 and 65 . Thus, national and international authorities consider that, until the age of 65 , pilots have the physical capabilities to act as a pilot, even if, between 60 and 65 , they do so only as a member of a crew in which the other pilots are younger than 60 .

93 The Act of 3 July 2002 r., OJ 2013, 1393, c.t. with amend.

94 See justification of the judgment in case Palacios de la Villa, pkt. 65: Furthermore, the Court has already held that encouragement of recruitment undoubtedly constitutes a legitimate aim of social policy (see, in particular, Case C-208/05 [2007] ECR I-181, paragraph 39) and that assessment must evidently apply to instruments of national employment policy designed to improve opportunities for entering the labour market for certain categories of workers.

95 See justification of the judgment in case Petersen, p. 68.

96 See the main thesis of the judgment of the EC in case Hesja. 
ployment contracts of building cleaners who have reached retirement age (65) are also compatible with Article 6(1) of the directive, as long as such a termination meets the criteria set forth in the said regulation.

However, it is not always the case that national regulations are found to be compatible with EU regulations. In its judgment of 18 November $2010^{97}$, ECJ analysed the rule of compulsory retirement of university professors ${ }^{98}$ and found that the quite enigmatic definition of the aim of Bulgarian regulations was insufficient and entailed a national court specifying the real aim of those regulations. To sum up, as long as the actual limitation of service in effect of expiry of employment contract of persons becoming eligible for retirement entitlements helps increase job opportunities for younger employees, the aim of disparate treatment is legitimate.

The European Court of Justice also explicitly emphasises that termination of employment contract does not automatically entail employees withdrawing from the labour market ${ }^{99}$. Does not the right to work of persons whose employment contract terminates automatically in some cases become only illusory due to the nature of their job, education background, and qualifications? No access to the given profession may actually really mean no opportunity to work at all, regardless of the abilities, experience, and specific fitness for work of the person concerned. Therefore, it is necessary not only to apply the narrowing interpretation of exceptions, but to assess the reasonability of their application, as well, considering the changes in the employment policy and in separate segments of the labour market, as well as the present situation of persons to whom that differentiating measure is applied. Hence, the ECJ is right to have committed national authorities, resolving disputes over refusals to apply national regulations that contravene the directive, to determine whether the national regulations are compatible with the directive (taking into account the transparency and adequacy of the differentiating measures to the aims pursued by the labour market policy ${ }^{100}$.

The principle of generational replacement, therefore, cannot be approached without consideration. Certain social or economic changes will justify the need to consider the option of continuing employment of persons reaching retirement age. This is the direction to be followed by Polish legislation and judicature, too. The right to work should emphasise the exceptional nature of dismissal policies,

97 In case (C-250/09) W. I. Georgiev v. Techniczeskiemu uniwersytetowi Sofia, filia Plowdiw, Lex, No. 612132.

98 Compare, the paragraph 51, in case of W. I. Georgiev.

99 See also the thesis contained in the justification to the judgment of EC in case Rosenblaudt, p. $68,74-77$.

100 See in particular paragraphs 81 in case Petersen, in which EC stresses that if national legislation does not satisfy the conditions set out in Article 6(1) of Directive 2000/78, the national court must decline to apply that legislation, even if provisions were in force before directive and even if the national law does not provide provisions that allow to refuse it's application. 
including that which determines the age limit for employment of older employees eligible for retirement so that they give up their jobs for the sake of younger employees. The bizarre transformation of the privilege that the right to retirement used to be into an obligation, referred to privilegium odiosum, may consequently lead to the loss of the right to work ${ }^{101}$. The cases judged by ECJ show quite a big, and still growing, discord between national regulations and the needs of contemporary employees who claim incompatibility with Article 6 of the Directive 2000/768/EC. Therefore, it feels right to deem reasonable the postulates for flexible and new understanding of retirement age by the legislature, doctrine and judicature which must take into consideration increased professional activity, as well as the growing tendency to increase retirement age in tune with the average life expectancy ${ }^{102}$.

101 Compare comments made by W. Szubert, op. cit., p. 109.

102 Compare B. Mikołajczyk, Retirement age..., p. 13 and 19-20. See also comments to the identified problem, contained in a monograph of the same author: International protection of the elderly, WKP 2012, Lex, No. 156494, part. I, The aging of humanity as a global problem, and point 1.2, The concept of older person and old age. 